\title{
Initial Development and Tolerance of Lettuce (Lactuca sativa) Cultivars Irrigated with Saline Water
}

\author{
Francisco V. da S. Sá ${ }^{1}$, Lauter S. Souto ${ }^{2}$, Emanoela P. de Paiva ${ }^{3}$, Rayane A. de Andrade ${ }^{2}$, Yuri B. de Lima ${ }^{1,2}$, \\ Fernanda A. de Oliveira $^{2}$, Miguel Ferreira Neto ${ }^{4} \&$ Rener L. de S. Ferraz ${ }^{1}$ \\ ${ }^{1}$ Academic Unit of Agricultural Engineering, Federal University of Campina Grande, Campina Grande, Brazil \\ ${ }^{2}$ Academic Unit of Agricultural Science, Federal University of Campina Grande, Pombal, Brazil \\ ${ }^{3}$ Department of Plant Production, Federal Rural University of Semi-Arid, Mossoró, Brazil \\ ${ }^{4}$ Department of Environmental and Technological Sciences, Federal Rural University of Semi-Arid, Mossoró, \\ Brazil \\ Correspondence: Francisco V. da S. Sá, Academic Unit of Agricultural Engineering, Federal University of \\ Campina Grande, Paraíba, Brazil. Tel: 55-083-99861-9267. E-mail: vanies_agronomia@hotmail.com
}

Received: June 26, 2017

doi:10.5539/jas.v9n9p149
Accepted: July 30, $2017 \quad$ Online Published: August 15, 2017

URL: https://doi.org/10.5539/jas.v9n9p149

\begin{abstract}
The objective was to study the initial development and tolerance of lettuce cultivars subjected to different levels of water salinity in the seedling production stage in order to determine the genotypes of the cultivars that are most sensitive and tolerant to saline water. The experiment was carried out in protected environment at the Center of Sciences and Agri-food Technology-CCTA of the Federal University of Campina Grande-UFCG, located in Pombal, Paraíba, Brazil, from August to September 2014. The study evaluated five lettuce cultivars

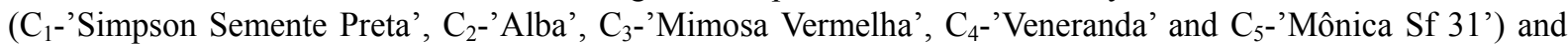
five levels of irrigation water salinity $\left(0.6\right.$ (control), 1.2, 1.8, 2.4 and $\left.3.0 \mathrm{dS} \mathrm{m}^{-1}\right)$, arranged in a factorial scheme $5 \times 5$, in a completely randomized experimental design, with four replicates. Plants were grown on trays for 20 days after sowing, period in which irrigations were daily applied, and evaluated for emergence, growth, phytomass accumulation and tolerance index of the lettuce cultivars. The increase in irrigation water salinity reduced emergence, growth and dry matter accumulation in the lettuce plants, and the cultivars $\mathrm{C}_{2}-{ }^{-} \mathrm{Alba}$ ' and $\mathrm{C}_{4}$-'Veneranda' were the most tolerant to salinity. Tolerance to salinity occurred in the following order $\mathrm{C}_{2}$-'Alba' $^{\prime}$ $=\mathrm{C}_{4}{ }^{-}$'Veneranda' $>\mathrm{C}_{1}{ }^{-}$'Simpson Semente Preta' $>\mathrm{C}_{3^{-}}{ }^{\prime}$ Mimosa Vermelha' $=\mathrm{C}_{5}{ }^{-}$'Mônica Sf 31' .
\end{abstract}

Keywords: genetic improvement, salinized water, irrigation, semi-arid region

\section{Introduction}

Lettuce (Lactuca sativa), belonging to the Asteraceae family, is a vegetable highly appreciated worldwide, generally consumed fresh in the form of salads. In Brazil, this vegetable has great economic and social importance, because its production has a relatively low cost, besides a high demand for labor, allowing small properties to cultivate it, thus generating jobs and income (Alves et al., 2011; Dias et al., 2011; Lúcio et al., 2011; Santos et al., 2011; Paulus et al., 2012).

In the Brazilian semi-arid region, this species has great importance, especially in family farming. However, water scarcity is a limiting factor for its cultivation, due to the low rainfall levels and annual rainfall irregularity (Medeiros et al., 2007). Thus, the producers are forced to utilize irrigation as a way to overcome this problem (Oliveira et al., 2011; Santos et al., 2011; Sarmento et al., 2014). However, the lower quality of the water available for agricultural use in this region leads to large problems in the economic potential of lettuce cultivation, due to the presence of high contents of salts in the irrigation water (Alves et al., 2011; Dias et al., 2011; Oliveira et al., 2011; Santos et al., 2011; Sarmento et al., 2014).

Among the negative factors of salinization, the excess of exchangeable sodium is the main limiting factor, causing soil sealing and leading to decrease in soil fertility, for reducing the availability of some nutrients to plants (Sá et al., 2013a; Mesquita et al., 2015). In the plants, due to the reduction in the osmotic potential of the soil, it limits the absorption of water and nutrients. In addition, it causes toxicity by ions $\left(\mathrm{Na}^{+}\right.$and $\left.\mathrm{Cl}^{-}\right)$that are absorbed by plants, reducing their development (Dias \& Blanco, 2010; Mesquita et al., 2015). 
In this context, saline water management strategies in the agriculture of arid and semi-arid regions are of fundamental importance for the development of these regions, requiring studies that allow the utilization of saline water in food production (Paulus et al., 2010). According to Medeiros et al. (2007), crop development and yield can be negatively affected depending on the quality of the utilized water, requiring the rational management of lower-quality water for the crop to have satisfactory and economically viable production.

Dias et al. (2011) and Oliveira et al. (2011), studying the response of lettuce cultivars to salinity, observed that the tolerance to salinity varies among the cultivars. Similar results were obtained by Sarmento et al. (2014), evaluating the quality and conservation of lettuce cultivated with desalination reject. Therefore, it is observed that there are still few studies evaluating the tolerance of lettuce cultivars and, in addition, the constant introduction of cultivars in the market generates the need for new characterizations that better express the cultivars in current agricultural use in the country.

Therefore, the objective was to study the initial development and tolerance of lettuce cultivars subjected to different levels of irrigation water salinity in the seedling production stage. The importance of studying different cultivars, subjected to different doses of irrigation water salinity, is to improve even more the work of the farmers, in the selection and moment to obtain a cultivar adaptable to their region, and determine the main genotypes of the cultivars with highest tolerance and sensitivity to salinized water. Hence, sensitivity, as well as tolerance, will depend on various factors, which can be environmental or due to genetic variability.

\section{Material and Methods}

\subsection{Localization, Experimental Procedure, Treatments and Plant Material}

The experiment was carried out in a protected environment of the Federal University of Campina Grande-UFCG, at the Center of Sciences and Agri-food Technology-CCTA, located in the municipality of Pombal-PB, Brazil, at the geographic coordinates $6^{\circ} 47^{\prime} 20^{\prime \prime} \mathrm{S}$ and $37^{\circ} 48^{\prime} 01^{\prime \prime} \mathrm{W}$ and $194 \mathrm{~m}$ altitude.

The study evaluated five lettuce cultivars $\left(\mathrm{C}_{1}\right.$-'Simpson Semente Preta', $\mathrm{C}_{2}$-'Alba', $\mathrm{C}_{3}$-'Mimosa Vermelha',

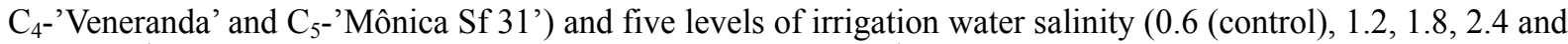
$3.0 \mathrm{dS} \mathrm{m}^{-1}$ ), two below the crop threshold salinity of $1.3 \mathrm{dS} \mathrm{m}^{-1}$ (Ayers \& Westcot, 1999) and three above it, in order to identify genotypes with higher tolerance or sensitivity to water salinity. The experiment was arranged in $5 \times 5$ factorial scheme, in a completely randomized design, with four replicates.

Lettuce plants were cultivated on trays of 30 cells with capacity for $0.1 \mathrm{dm}^{3}$ of substrate, until 30 days after sowing (DAS). The substrate for seedling production was composed of soil (Fluvic Neosol) (Santos et al., 2013) and commercial substrate at the proportion of 1:1, respectively (Table 1).

Table 1. Chemical characteristics of the components of the substrate used for lettuce cultivation

\begin{tabular}{|c|c|c|c|c|c|c|c|c|c|c|c|c|}
\hline & EC & $\mathrm{pH}$ & $\mathrm{P}$ & $\mathrm{K}^{+}$ & $\mathrm{Ca}^{+2}$ & $\mathrm{Mg}^{+2}$ & $\mathrm{Na}^{+}$ & $\mathrm{Al}^{3+}$ & $\mathrm{H}^{+}+\mathrm{Al}^{3+}$ & SB & $\mathrm{T}$ & $\mathrm{OM}$ \\
\hline & $\mathrm{dS} \mathrm{m}^{-1}$ & $\mathrm{H}_{2} \mathrm{O}$ & $\mathrm{mg} \mathrm{dm}$ & --.-- & - & ------. & ----- & $\mathrm{ol}_{\mathrm{c}} \mathrm{dm}$ & -------. & . & --------- & $\mathrm{g} \mathrm{kg}^{-3}$ \\
\hline A & 0.09 & 8.07 & 3.00 & 0.32 & 6.40 & 3.20 & 0.18 & 0.00 & 0.00 & 10.49 & 10.49 & 16.0 \\
\hline B & 1.65 & 5.75 & 86.00 & 1.67 & 11.60 & 28.50 & 17.84 & 0.00 & 11.88 & 59.61 & 71.49 & 570.0 \\
\hline
\end{tabular}

Note. $\mathrm{SB}=$ sum of bases; $\mathrm{EC}=$ electrical conductivity; $\mathrm{T}=$ total cation exchange capacity; $\mathrm{OM}=$ organic matter; $\mathrm{A}=$ Soil; $\mathrm{B}=$ commercial substrate.

\subsection{Establishment and Management of the Experiment}

At sowing, thirty cells were used in each treatment, so that each cell received one seeds, totaling thirty seeds per treatment. After total emergence, thinning was performed to leave only the most vigorous plant per cell. The seeds of both cultivars were purchased in commercial establishment, with $99 \%$ of purity and $95 \%$ of germination.

Irrigations were daily applied to leave the soil with moisture close to the retention capacity, based on the drainage lysimetry method, in which the applied water depth was added of a leaching fraction (LF) of $20 \%$. The volume applied per container $\left(\mathrm{V}_{\mathrm{a}}\right)$ was obtained by the difference between the previous volume applied $\left(\mathrm{V}_{\text {prev }}\right)$ and mean drainage (d), divided by the number of containers (n), as indicated in Equation 1:

$$
V_{a}=\frac{V_{\text {prev }}-D}{n(1-L F)}
$$


The preparation of irrigation water with different salinity levels considered the relationship between Electrical conductivity of water-EC $\mathrm{w}_{\mathrm{w}}$ and concentration of salts $\left(10 \cdot \mathrm{meq} \mathrm{L}^{-1}=1 \mathrm{dS} \mathrm{m}^{-1}\right.$ of $\left.\mathrm{EC}_{\mathrm{w}}\right)$, according to Rhoades et al. (1992), valid for $\mathrm{EC}_{\mathrm{w}}$ from 0.1 to $5.0 \mathrm{dS} \mathrm{m}^{-1}$, an interval that encompasses the tested levels. Local supply water was used $\left(\mathrm{EC}_{\mathrm{w}}=0.3 \mathrm{dS} \mathrm{m}^{-1}\right)$, mixed with salts $(\mathrm{NaCl})$ as necessary (Table 2).

Table 2. Chemical analysis of the supply water used to prepare the solutions.

\begin{tabular}{llllllllllll}
\hline \multirow{3}{*}{ Water } & $\mathrm{EC}_{\mathrm{a}}$ & $\mathrm{pH}$ & $\mathrm{K}$ & $\mathrm{Ca}$ & $\mathrm{Mg}$ & $\mathrm{Na}$ & $\mathrm{SO}_{4}^{-2}$ & $\mathrm{CO}_{3}^{-2}$ & $\mathrm{HCO}_{3}^{-}$ & $\mathrm{Cl}^{-}$ & $\mathrm{SAR}^{1}$ \\
\cline { 2 - 9 } & $\mathrm{dS} \mathrm{m}{ }^{-1}$ & & ---1.0 & -1.0 & 2.21 \\
\hline
\end{tabular}

Note. $\mathrm{EC}=$ electrical conductivity; $\mathrm{SAR}=$ Sodium adsorption ratio.

After preparation, the salinized waters were stored in $30-\mathrm{L}$ plastic containers, one for each $\mathrm{EC}_{\mathrm{w}}$ level, properly protected to avoid evaporation, entry of rainwater and contamination by materials that could compromise the quality. To prepare the waters with the specific electrical conductivities (EC), the salts were weighed according to the treatment, and water was added until reaching the desired EC levels, which were confirmed using a portable conductivity meter with conductivity adjusted to the temperature of $25^{\circ} \mathrm{C}$.

\subsection{Traits Measured}

During the experiment, the emergence of lettuce plants was monitored through the counts of emerged seedlings, i.e., with cotyledons above the soil level, performed daily and without discarding the plants, thus generating a cumulative value. Hence, the number of emerged plants relative to each count was obtained by subtracting the reading of the previous day from the recently obtained value.

Therefore, the number of emerged seedlings referring to each reading, obtained inprotected environment, was used to calculate the germination speed index (ESI), adopting the equation (Equation 2) described in Schuab et al. (2006):

$$
\mathrm{ESI}=\frac{\left(\mathrm{N}_{1}\right)+\left(\mathrm{N}_{2}\right)+\ldots+\left(\mathrm{N}_{\mathrm{n}}\right)}{\mathrm{G}_{1}+\mathrm{G}_{2}+\ldots+\mathrm{G}_{\mathrm{n}}}
$$

Where, ESI = germination speed index; $\mathrm{G}=$ number of emerged plants observed in each count; $\mathrm{N}=$ number of days from sowing to each count.

After stabilization of emergence, emergence percentage (EP) (\%) was obtained through the relationship between the number of emerged plants and the number of planted seeds.

The morphological aspects of the crop were monitored through the growth analysis of the seedlings at 20 DAS, evaluating the number of leaves (NL), based on the count of mature leaves. After the growth analysis, the plants were collected, separated into shoots and roots, and dried in a forced-air oven at $65{ }^{\circ} \mathrm{C}$ until constant weight. Then, the material was weighed on analytical scale to determine shoot dry matter (SDM) (g) and root dry matter (RDM) (g). These data were used to determine the total dry matter (TDM) through the sum of SDM and RDM. The root/shoot ratio (R/S) was obtained by dividing RDM by SDM.

These data of total dry matter production were used to calculate the percentages partitioned among the vegetative organs and the salinity tolerance index (STI), comparing the data of saline treatments with those of the control $\left(\mathrm{EC}_{\mathrm{w}}=0.6 \mathrm{dS} \mathrm{m}{ }^{-1}\right)$, according to the methodology of Fageria et al. (2010), based on four levels of classification: T (tolerant; 0-20\%), MT (moderately tolerant; $21-40 \%$ ), MS (moderately sensitive; 41-60\%) and S (sensitive; > $60 \%)$, as shown in Equation 3:

$$
S T I=\frac{\text { TDM poduction in the saline treatment }}{\text { TDM poduction in the control treatment }} \times 100
$$

These indices were calculated using the total dry matter production of the genotypes as the main parameter to determine the tolerance of the materials to salt stress.

\subsection{Statistical Analysis}

The obtained data were subjected to analysis of variance by $\mathrm{F}$ test and, in cases of significance, regression analyses were applied for the factor levels of irrigation water salinity and Tukey test was applied for the factor cultivars, both at 0.05 probability level, using the statistical program SISVAR ${ }^{\circ}$ (Ferreira, 2011). The data were submitted to standardization, with zero mean $(\overline{\mathrm{X}}=0)$ and variance one $(\sigma=1)$. Thereafter, it proceeded by 
hierarchical cluster analysis method, Ward's minimum variance, using as a dissimilarity measure Euclidean distance (Hair et al., 2009).

\section{Results and Discussion}

There was significant interaction $(\mathrm{p}>0.05)$ between the lettuce cultivars and the levels of irrigation water salinity for the variables emergence percentage, germination speed index, number of leaves, shoot dry matter, root dry matter, total dry matter and salinity tolerance index (Figures 1, 2, and 3).

Emergence percentage (EP) and germination speed index (ESI) of lettuce plants were reduced by the increase in irrigation water salinity and showed linear reductions on the order of $18.52,10.19$ and $17.59 \%$ for EP and 0.28 , 0.13 and 0.24 for ESI, relative to the cultivars $\mathrm{C}_{1}{ }^{-}$'Simpson Semente Preta', $\mathrm{C}_{2}{ }^{-}{ }^{-} \mathrm{Alba}$ ' and $\mathrm{C}_{4}{ }^{-}{ }^{-}$Veneranda', for

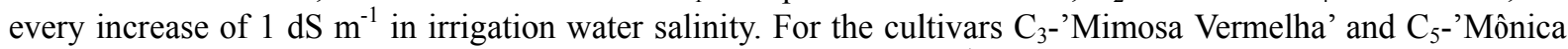
Sf 31', EP and ESI were equal to zero from the level of $2.4 \mathrm{dS} \mathrm{m}^{-1}$ on, denoting the high sensitivity of these cultivars to salt stress, compared with the others (Figure 1A). Additionally, the cultivar $\mathrm{C}_{2}$-'Alba' showed the highest indices of vigor at all salinity levels, thus denoting higher tolerance in comparison to the others in the germination stage. The effects of salinity on plants may be related to the difficulty to absorb water, due to the increase in soil osmotic potential and, consequently, causing water stress on the seed, affecting imbibition and thus preventing them from emerging or even germinating in the saline substrate (Taiz \& Zeiger, 2013; Albuquerque et al., 2016). Reductions in plant emergence and vigor due to the increase of salinity were also observed in vegetables such as cabbage (Oliveira et al., 2015), cucumber (Albuquerque et al., 2016) and coriander (Sá et al., 2016), and the authors attributed these reductions to the increase in the osmotic potential, which restricts imbibition, affecting germination and emergence of the plants.

A

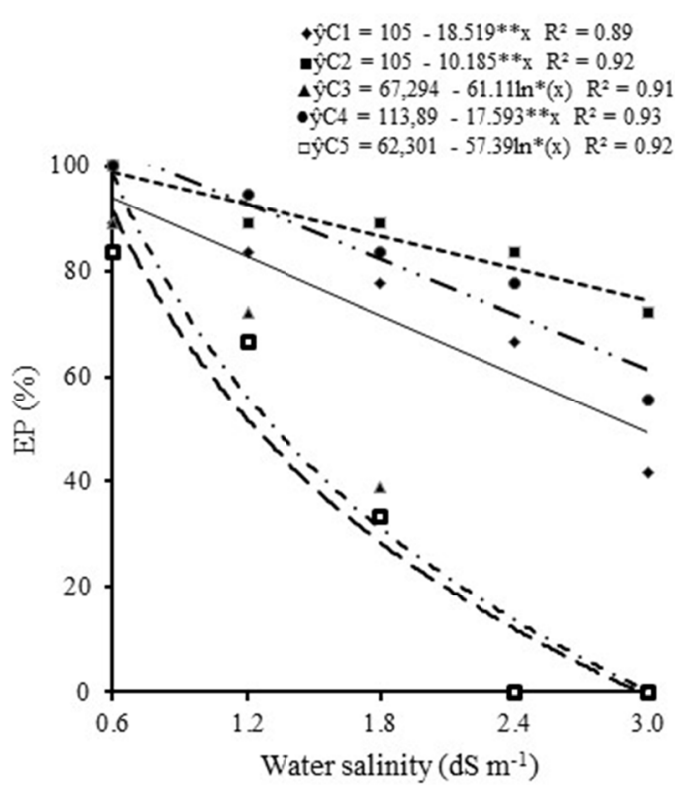

B

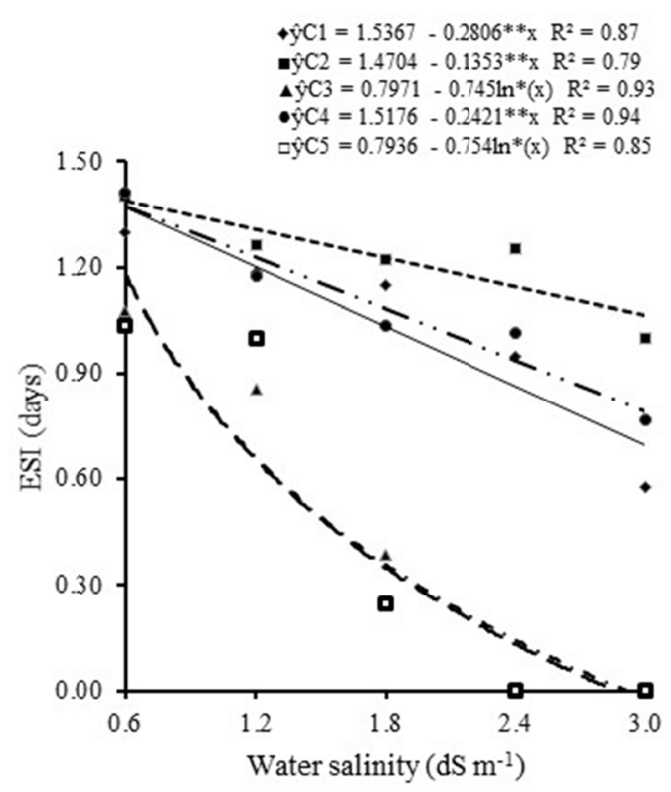

Figure 1. Emergence percentage, EP\% (A) and germination speed index, ESI (B) of lettuce cultivars ( $\mathrm{C}_{1}{ }^{-}$'Simpson Semente Preta'; $\mathrm{C}_{2}{ }^{\prime}$ 'Alba'; $\mathrm{C}_{3}$-'Mimosa Vermelha'; $\mathrm{C}_{4}{ }^{-}$Veneranda' and $\mathrm{C}_{5}$-'Mônica Sf 31') under salt stress in the initial growth stage

Note. $* *$ and $*=$ significant at 0.01 and 0.05 probability levels $(\mathrm{p}<0.01$ and $\mathrm{p}<0.05)$.

There was significant influence $(p<0.05)$ of the interaction between cultivars and levels of irrigation water salinity on the number of leaves (NL) of lettuce plants (Figure 2A). Only in the cultivar 'Simpson Semente Preta', there was no influence of salinity on the number of leaves, with mean value of 4 leaves per plant (Figure 2A). In the other cultivars, the NL was reduced by the increase in salinity and the highest reductions occurred in

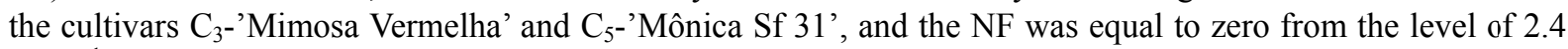
$\mathrm{dS} \mathrm{m}^{-1}$ on. It should be highlighted that the production of leaves by these cultivars was lower than that of the others from $1.2 \mathrm{dS} \mathrm{m}^{-1}$ on. For the cultivars $\mathrm{C}_{2}{ }^{-}$'Alba' and $\mathrm{C}_{4}{ }^{-}$'Veneranda', there was a decreasing linear 
behavior with reductions of 31.38 and $31.96 \%$, comparing the highest $\left(3.0 \mathrm{dS} \mathrm{m} \mathrm{m}^{-1}\right)$ and lowest $\left(0.6 \mathrm{dS} \mathrm{m}^{-1}\right)$ salinity levels (Figure 2A). Reductions in the number of leaves of lettuce plants were also observed by Alves et al. (2011) (cv. 'Verônica') and Dias et al (2011) (cv. 'Babá de verão' and cv. 'Verônica'), in hydroponic cultivation, subjected to different saline levels of the nutrient solution.

The highest reductions in the accumulation of shoot dry matter (SDM), root dry matter (RDM) and total dry matter (TDM) were observed in plants of the cultivars $\mathrm{C}_{3}$-'Mimosa Vermelha' and $\mathrm{C}_{5}$-'Mônica Sf 31 ', with null value of SDM, RDM and TDM from the level of $2.4 \mathrm{dS} \mathrm{m}^{-1}$ on. There were also reductions of 70.47, 69.34 and $70.16 \%$ in the SDM, RDM and TDM of the cultivar $\mathrm{C}_{3}{ }^{-}{ }^{-}$Mimosa Vermelha' and of $65.72,64.71$ and $65.55 \%$ in

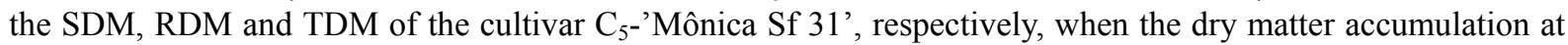
the level $1.8 \mathrm{dS} \mathrm{m}^{-1}$ was compared with the lowest salinity level $\left(0.6 \mathrm{dS} \mathrm{m}^{-1}\right)$ (Figures 2B, 2C and 2D).

For the cultivar $\mathrm{C}_{1}$-'Simpson Semente Preta', there were reductions of $86.0 \%$ in SDM accumulation, comparing the highest $\left(3.0 \mathrm{dS} \mathrm{m}^{-1}\right)$ and lowest $\left(0.6 \mathrm{dS} \mathrm{m}^{-1}\right)$ salinity levels (Figure $\left.2 \mathrm{~B}\right)$. RDM accumulation in this cultivar exhibited a quadratic response with increment in dry matter accumulation up to the level of $1.9 \mathrm{dS} \mathrm{m}^{-1}$, with subsequent reductions (Figure 2B). This behavior may be related to the tolerance mechanism of the species, investing in greater growth of the root system in order to escape from the salt stress conditions. According to Sá et al. (2013b), this behavior is inefficient, because the larger the root system the higher the absorption of water and, consequently, of salts by the plants, intensifying the condition of stress. This fact has been confirmed in the present study, because this mechanism did not prevent the reduction in SDM and TDM accumulation in the plants of this cultivar.

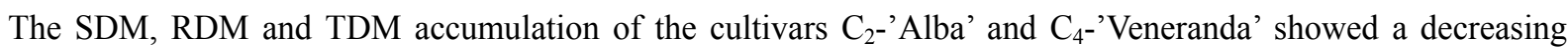
linear response to the increment in irrigation water salinity, with unit reductions of $1.36,0.28$ and $1.64 \mathrm{mg}$ in SDM, RDM and TDM of the cultivar $\mathrm{C}_{2}{ }^{\prime}$ 'Alba' and of 1.43, 0.48 and $1.78 \mathrm{mg}$ in SDM, RDM and TDM of the cultivar $\mathrm{C}_{4}$-'Veneranda', for every increase of $1 \mathrm{dS} \mathrm{m}^{-1}$ in irrigation water salinity, respectively (Figures 2B, 2C and 2D). This behavior is due to the high concentrations of sodium salts, which negatively interact with the physiology of the plants, for promoting deleterious ionic, osmotic and nutritional interactions in plants, directly affecting biomass accumulation (Munns \& Tester, 2008; Taiz \& Zeiger, 2013; Sá et al., 2013b; Albuquerque et al., 2016). Paulus et al. (2010) obtained similar results in their studies with hydroponic lettuce and observed reduction in shoot dry matter accumulation as the salinity levels increased. 
A

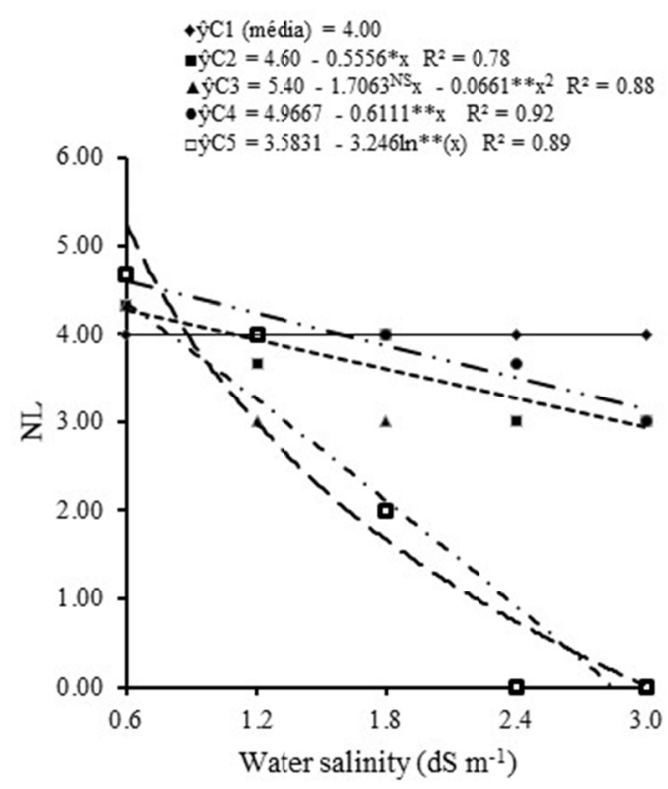

$\mathrm{C}$

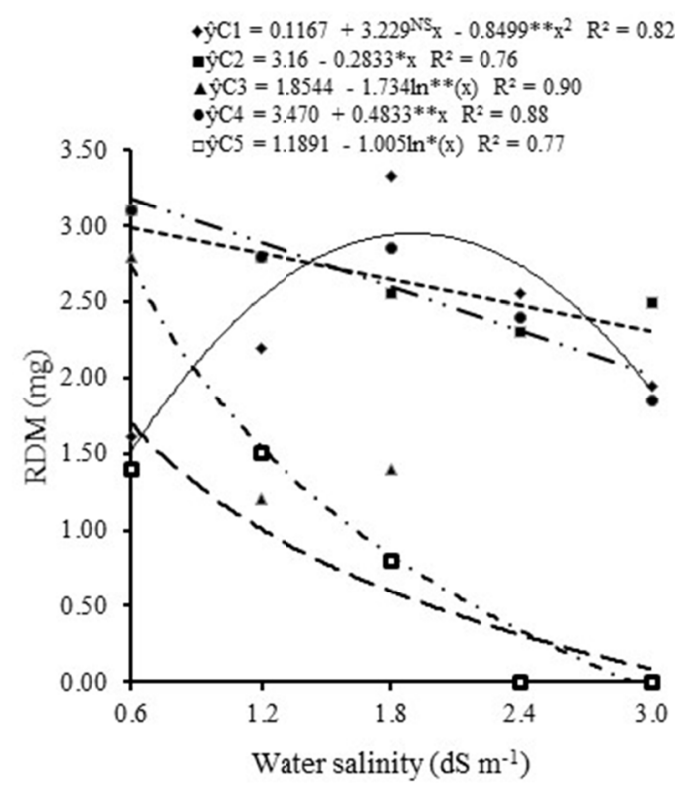

B

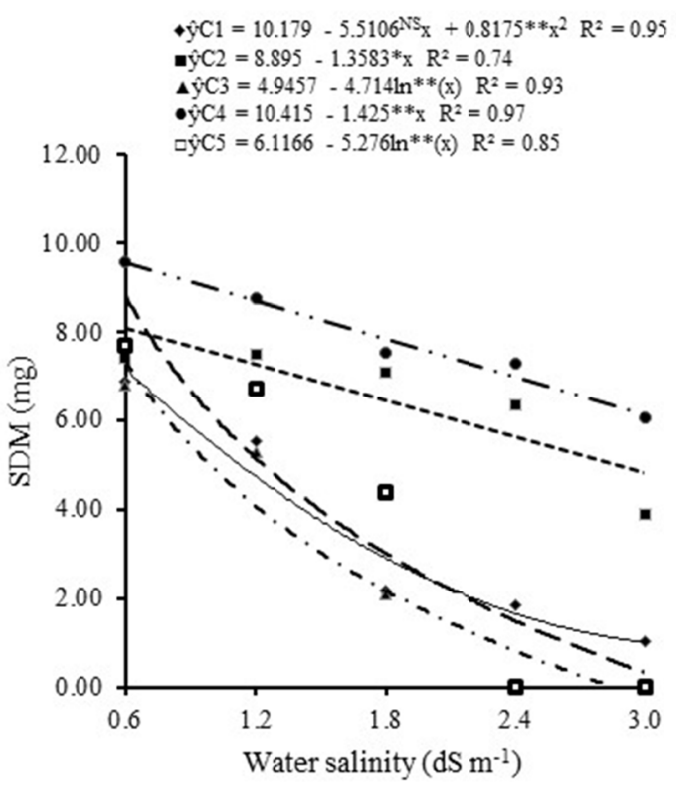

$\mathrm{D}$

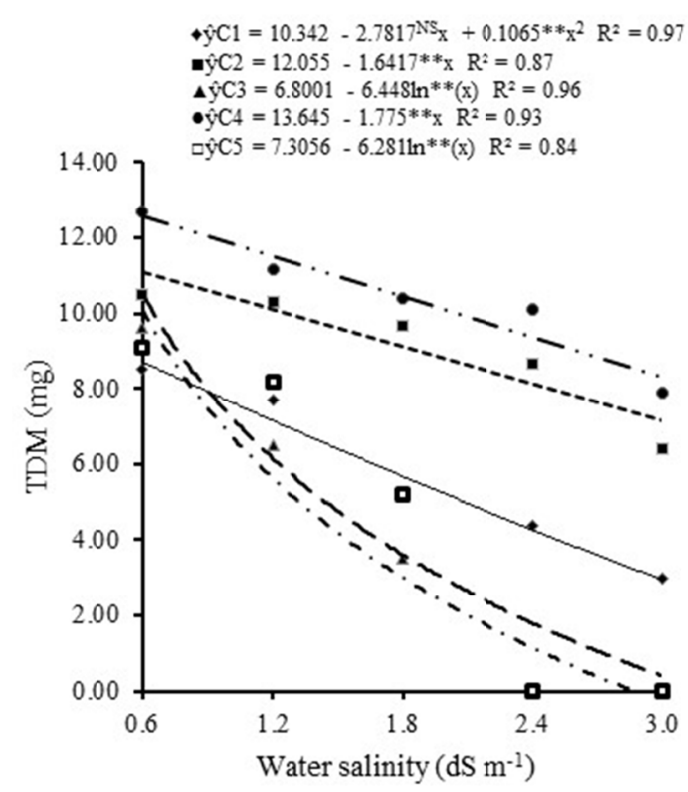

Figure 2. Number of leaves, NL (A), shoot dry matter, SDM (B), root dry matter, RDM (C) and total dry matter,

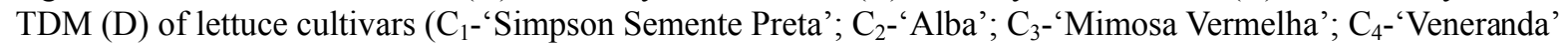
and $\mathrm{C}_{5^{-}}$'Mônica $\mathrm{Sf} 31^{\prime}$ ') under salt stress in the initial growth stage

Note. ${ }^{\mathrm{NS}},{ }^{* *}$ and $*=$ not significant $(\mathrm{p}>0.05)$; significant at 0.01 and 0.05 probability levels $(\mathrm{p}<0.01$ and $\mathrm{p}<$ $0.05)$.

Regarding the salinity tolerance index, the cultivars $\mathrm{C}_{2}{ }^{-}$'Alba' and $\mathrm{C}_{4}{ }^{-}$'Veneranda' are the most tolerant to salinity, showing moderate tolerance up to the salinity level of $3.0 \mathrm{dS} \mathrm{m}^{-1}$, according to the classification of Fageria et al. (2010), based on four levels: T (tolerant; 0-20\%), MT (moderately tolerant; 21-40\%), MS (moderately sensitive; 41-60\%) and $\mathrm{S}$ (sensitive; $>60 \%$ ). According to this classification, the cultivars

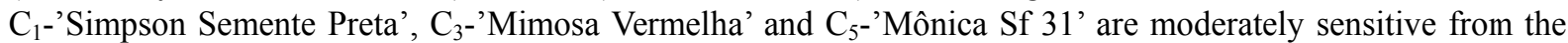
levels of 2.1, 1.4 and $1.4 \mathrm{dS} \mathrm{m}^{-1}$ on, respectively (Figure 3). 


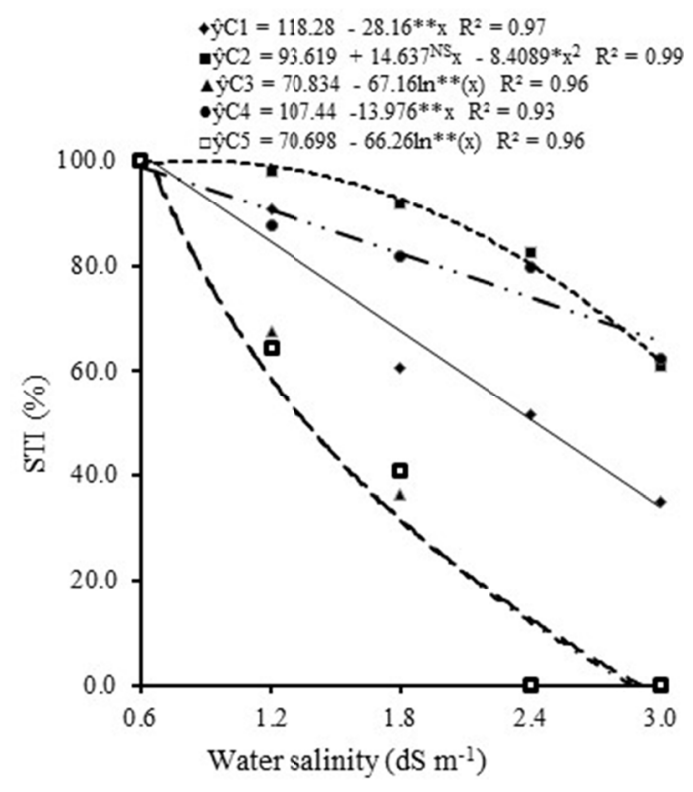

Figure 3. Salinity tolerance index (STI) of lettuce cultivars $\left(\mathrm{C}_{1}\right.$-'Simpson Semente Preta'; $\mathrm{C}_{2}$ ' $^{\text {'Alba'; }}$

$\mathrm{C}_{3}$-'Mimosa Vermelha'; $\mathrm{C}_{4}$-'Veneranda' and $\mathrm{C}_{5}$-'Mônica $\mathrm{Sf} 31$ ') under salt stress in the initial growth stage

Note. ${ }^{\mathrm{NS}}, * *$ and $*=$ not significant $(\mathrm{p}>0.05)$; significant at 0.01 and 0.05 probability levels $(\mathrm{p}<0.01$ and $\mathrm{p}<$ $0.05)$.

Based on the Euclidian Distance as a measure of dissimilarity, four groups of salinity (S) and lettuce cultivar (C) combinations were formed. The first (I) and second (II) conglomerates can be characterized by low salinity and high performance for germination and aerial and root phytomass allocation. In these two groups, it is possible to highlight $\mathrm{C}_{2}$ and $\mathrm{C}_{4}$ cultivars, which, even under high salinity levels $\left(1.8,2.4\right.$ and $\left.3.0 \mathrm{dS} \mathrm{m}^{-1}\right)$, maintained a high performance, denoting tolerance of these genotypes to salinity (Figure 4). The third (III) and fourth (IV) groups are characterized by high salinity and low performance for germination and dry matter accumulation of shoot and root, with cultivars $\mathrm{C}_{1}, \mathrm{C}_{3}$ and $\mathrm{C}_{5}$ being the most sensitive to salinity with significant reduction of performance In the following order $C_{1}>C_{3}>C_{5}$ (Figure 4). The results observed in the proceeded by hierarchical cluster analysis method corroborate with those observed in the indent of tolerance to salinity (Figures 3 and 4). 


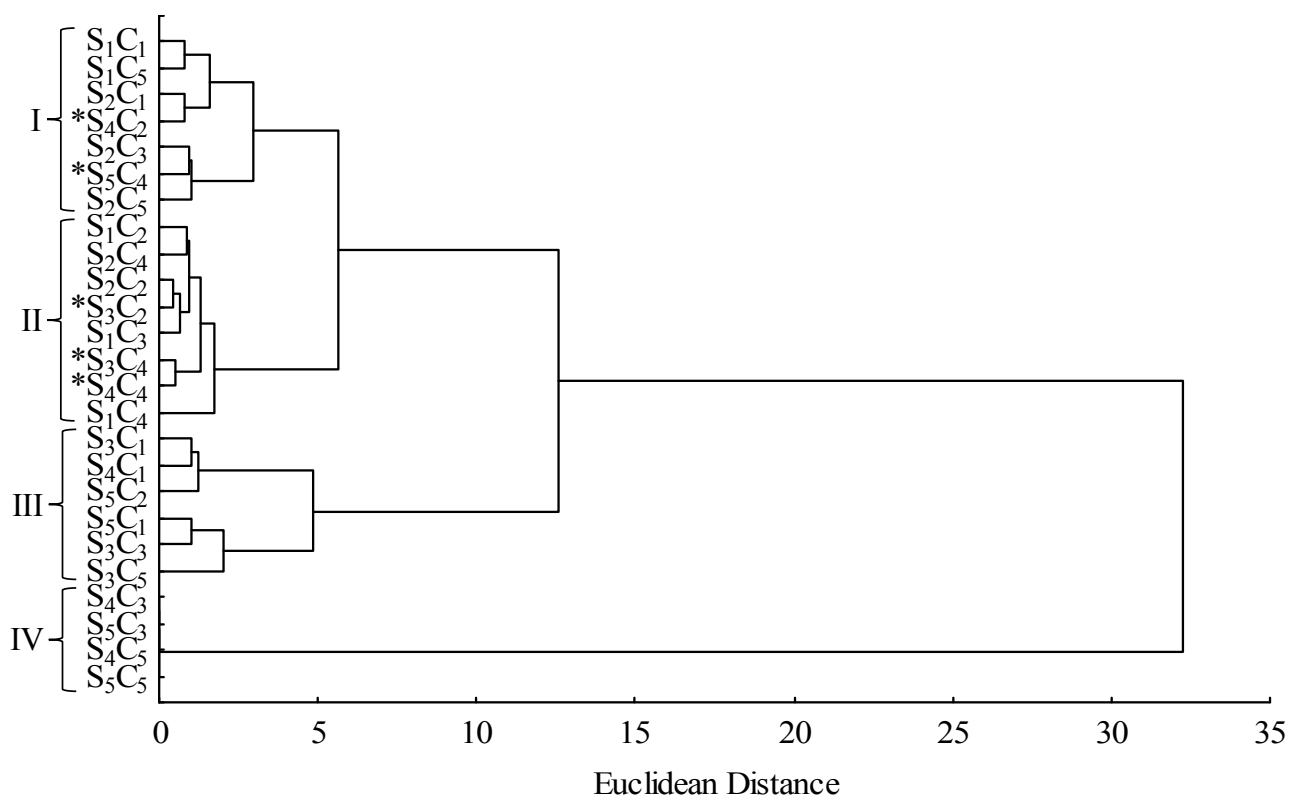

Figure 4. Dendrogram of dissimilarity of the groups formed by the combination of salinity levels (S1-0.6, S2-1.2, S3-1.8, S4-2.4 and S5-3.0 dS m $\left.{ }^{-1}\right)$ and lettuce cultivars $\left(\mathrm{C}_{1}\right.$-'Simpson Black Seed', $\mathrm{C}_{2}{ }^{-}{ }^{-}$Alba', $\mathrm{C}_{3}{ }^{-}{ }^{-}$Mimosa

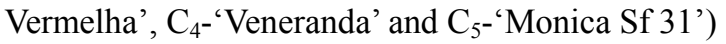

\section{Conclusion}

The increase in irrigation water salinity reduces emergence, growth and dry matter accumulation of lettuce plants,

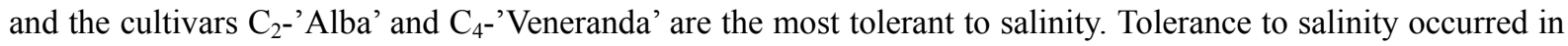
the following order: $\mathrm{C}_{2}{ }^{\prime}{ }^{\prime}$ Alba' $=\mathrm{C}_{4}{ }^{\prime}$ Veneranda' $>\mathrm{C}_{1}{ }^{\prime}{ }^{\prime}$ Simpson Semente Preta' $>\mathrm{C}_{3}$-'Mimosa Vermelha' $^{\prime}=$

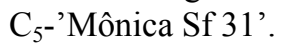

\section{References}

Albuquerque, J. R. T., Sá, F. V. S., Oliveira, F. A., Paiva, E. P., Araújo, E. B. G., \& Souto, L. S. (2016). Crescimento inicial e tolerância de cultivares de pepino sob estresse salino. Rev. Bras. de Agric. Irrigada., 10(3), 486-495. https://doi.org/10.7127/rbai.v10n200355

Alves, M. S., Soares, T. M., Silva, L. T., Fernandes, J. P., Oliveira, M. L. A., \& Paz, V. P. S. (2011). Estratégias de uso de água salobra na produção de alface em hidropônica NFT. Rev. Bras. de Eng. Agrí. Ambiental., 15(5), 491-498. https://doi.org/10.1590/S1415-43662011000500009

Ayers, R. S., \& Westcot, D. W. (1999). A qualidade da água na agricultura (2nd ed., p. 153). Campina Grande: UFPB; Estudos FAO: Irrigação e Drenagem, 29 Revisado.

Dias, N. S., \& Blanco, F. F. (2010). Efeitos dos sais no solo e na planta. In H. R. Gheyi, N. S. Dias, \& C. F. Lacerda (Eds.), Manejo da salinidade na agricultura: estudos básicos e aplicados (p. 129). Fortaleza, CE. INCT Sal.

Dias, N. S., Sousa Neto, O. N., Cosme, C. R., Jales, A. G. O., Rebouças, J. R. L., \& Oliveira, A. M. (2011). Resposta de cultivares de alface à salinidade da solução nutritiva com rejeito salino em hidroponia. Rev. Bras. de Eng. Agrí. Ambiental., 15(10), 991-995. https://doi.org/10.1590/S1415-43662011001000001

Fageria, N. K., Soares Filho, W. S., \& Gheyi, H. R. (2010). Melhoramento genético vegetal e seleção de espécies tolerantes à salinidade. In H. R. Gheyi, N. S. Dias, \& C. F. Lacerda (Eds.), Manejo da salinidade na agricultura: estudos básicos e aplicados (pp. 205-216). Fortaleza, CE. INCT Sal.

Ferreira, D. F. (2011). Sisvar: A computer statistical analysis system. Ciênência \& Agrotecnologia, 35(6), 1039-1042. https://doi.org/10.1590/S1413-70542011000600001

Hair, J. F., Black, W. C., Babin, B. J., Anderson, R. E., \& Tatham, R. L. (2009). Análise multivariada de dados (6th ed., p. 688). Porto Alegre: Bookman. 
Lúcio, A. D., Haesbaert, F. M., Santos, D., \& Benz, V. (2011). Estimativa do tamanho de parcela para experimentos com alface. Horticultura. Brasileira., 29(4), 510-515. https://doi.org/10.1590/S0102-0536201 1000400011

Medeiros, J. F., Marcelo, C. C., Sarmento, D. H. A., \& Barros, A. D. (2007). Crescimento do meloeiro cultivado sob diferentes níveis de salinidade, com e sem cobertura do solo. Rev. Bras. de Eng. Agrí. Ambiental., 11(3), 248-255. https://doi.org/10.1590/S1415-43662007000300002

Mesquita, E. F., Sá, F. V. S., Bertino, A. M. P., Cavalcante, L. F., Paiva, E. P., \& Ferreira, N. M. (2015). Effect of soil conditioners on the chemical attributes of a saline-sodic soil and on the initial growth of the castor bean plant. Semima: Ciên. Agrárias., 36(4), 2527-2538. https://doi.org/10.5433/1679-0359.2015v36n4p2527

Munns, R., \& Tester, M. (2008). Mechanisms of salinity tolerance. Ann. Rev. Plant Biology, 59(6), 651-681. https://doi.org/10.1146/annurev.arplant.59.032607.092911

Oliveira, F. A., Carrilho, M. J. S. O., Medeiros, J. F., Maracajá, P. B., \& Oliveira, M. K. T. (2011). Desempenho de cultivares de alface submetidas a diferentes níveis de salinidade da água de irrigação. Rev. Bras. de Eng. Agrí. Ambiental., 15(8), 771-777. https://doi.org/10.1590/S1415-43662011000800002

Oliveira, F. A., Sá, F. V. S., Paiva, E. P., Araújo, E. B. G., Silva, M. K. N., Andrade, R. A., ... Souto, L. S. (2015). Emergência e crescimento inicial de plântulas de repolho cv. Chato de Quintal sob estresse salino. Agropecuária Técnica, 36(1), 273-279. https://doi.org/10.25066/agrotec.v36i1.24682

Paulus, D., Dourado Neto, D., Frizzone, J. A., \& Soares, T. M. (2010). Produção e indicadores fisiológicos de alface sob hidroponia com água salina. Horticultura Brasileira, 28(1), 29-35. https://doi.org/10.1590/ S0102-05362010000100006

Paulus, D., Paulus, E., Nava, G. A., \& Moura, C. A. (2012). Crescimento, consumo hídrico e composição mineral de alface cultivada em hidroponia com águas salinas. Rev. Ceres, 59(1), 110-117. https://doi.org/ 10.1590/S0034-737X2012000100016

Rhoades, J. D., Kandiah, A., \& Mashali, A. M. (1992). The use of saline waters for crop production. Irrigation and Drainage Paper, 48 (p. 133). Rome: FAO.

Sá, F. V. S., Araújo, J. L., Novais, M. C., Silva, A. P., Pereira, F. H. F., \& Lopes, K. P. (2013a). Crescimento inicial de arbóreas nativas em solo salino-sódico do nordeste brasileiro tratado com corretivos. Rev Cer., 60(3), 388-396. https://doi.org/10.1590/S0034-737X2013000300012

Sá, F. V. S., Brito, M. E. B., Melo, A. S., Antonio Neto, P., Fernandes, P. D., \& Ferreira, I. B. (2013b). Produção de mudas de mamoeiro irrigadas com água salina. Rev. Bras. de Eng. Agrí. Ambiental., 17(10), 1047-1054. https://doi.org/10.1590/S1415-43662013001000004

Sá, F. V. S., Souto, L. S., Paiva, E. P., Ferreira Neto, M., Silva, R. A., Silva, M. K. N., ... Alves Neto, A. (2016). Tolerance of coriander cultivars under saline stress. Afric. J. of Agricultural Res., 11(26), 3728-3732. https://doi.org/10.5897/AJAR2016.11390

Santos, A. N., Silva, E. F. F., Soares, T. M., Dantas, R. M. L., \& Silva, M. M. (2011). Produção de alface em NFT e Floating aproveitando água salobra e o rejeito da dessalinização. Rev. Ciên. Agronômica., 42(2), 319-326. https://doi.org/10.1590/S1806-66902011000200009

Santos, H. G., Jacomine, P. K. T., Anjos, L. H. C., Oliveira, V. A., \& Oliveira, J. B. (2013). Sistema Brasileiro de Classificação dos Solos (2th ed., p. 353). Rio de Janeiro, Embrapa Solos.

Sarmento, J. D. A., Morais, P. L. D., Almeida, M. L. B., Sousa Neto, O. N., \& Dias, N. S. (2014). Qualidade e conservação da alface cultivada com rejeito da dessalinização. Rev. Caatinga., 27(3), 90-97.

Schuab, S. R. P., Braccini, A. L., França Neto, J. B., Scapim, C. A., \& Meschede, D. K. (2006). Potencial físiológico de sementes de soja e sua relação com a emergência das plântulas em campo. Acta Scien. Agronomy, 28(4), 553-561.

Taiz, L., \& Zeiger, E. (2013). Fisiologia vegetal (5th ed., p. 918). Porto Alegre: Artmed.

\section{Copyrights}

Copyright for this article is retained by the author(s), with first publication rights granted to the journal.

This is an open-access article distributed under the terms and conditions of the Creative Commons Attribution license (http://creativecommons.org/licenses/by/4.0/). 